\title{
Baseline Sensitivity and Control Efficacy of Tetramycin Against Phytophthora capsici Isolates in China
}

Dicheng Ma, Jiamei Zhu, Leiming He, Kaidi Cui, Wei Mu, and Feng Liu, ${ }^{\dagger}$ College of Plant Protection, Shandong Agricultural University, Shandong Provincial Key Laboratory for Biology of Vegetable Diseases and Insect Pests, Tai' an, Shandong 271018, P.R. China

\begin{abstract}
Tetramycin is a new biopesticide that combines high-level and broadspectrum fungicidal activity, low toxicity, and environmental safety. In this study, 90 Phytophthora capsici isolates obtained from various regions in southern China were characterized for their baseline sensitivity to tetramycin. The protective and curative activities of tetramycin against $P$. capsici were determined on leaves of pepper, and the control efficacy of tetramycin in greenhouse experiments was also determined. Compared with mycelial growth, the formation of sporangia and the discharge of zoospores were inhibited by lower concentrations of tetramycin, approximately $5 \mu \mathrm{g} \mathrm{ml}^{-1}$ on V8 media. The frequency distribution curves for the tetramycin sensitivity were unimodal, with mean values for the fungicide concentration that

reduced mycelial growth, sporangia formation, and zoospore discharge by $50 \%$ compared with the control of $1.18 \pm 0.91,0.64 \pm 0.42$, and $0.63 \pm$ $0.30 \mu \mathrm{g} \mathrm{ml}^{-1}$, respectively. In addition, no correlation was observed between tetramycin and other fungicides tested, including mandipropamid, azoxystrobin, mefenoxam, fluazinam, fluopicolide, and famoxadone. Tetramycin exhibited both protective and curative effects against $P$. capsici in vitro, and its protective activity was better than its curative activity. In greenhouse experiments, tetramycin concentration of 60 and $90 \mu \mathrm{g} \mathrm{ml} l^{-1}$ provided a protective control efficacy of 47.1 to $56.4 \%$ and curative efficacy of 43.3 to $52.7 \%$. These results demonstrated that tetramycin could serve as an excellent alternative fungicide to control Phytophthora blight of pepper.
\end{abstract}

Phytophthora capsici Leonian is a widespread and highly damaging plant pathogen (Jang et al. 2009). It infects many economically important crops, including pepper, watermelon, tomato, pumpkin, snap bean, and cucumber, causing rot on the roots and crown (Hausbeck and Lamour 2004; Lamour et al. 2011; Rubin et al. 2008). P. capsici spreads primarily through soil and water movement, thereby enhancing the difficulty of managing this disease (Granke et al. 2009; Ristaino et al. 1994).

Currently, the application of chemical fungicides is identified as the principal tool for managing diseases caused by $P$. capsici (Bi et al. 2011). There are several fungicides with different modes of that action registered against Phytophthora blight of pepper in China, including phenylamides, carboxylic acid amides, strobilurins, alkyl hydrochlorides, oxazoles, and amino acids (http://www.chinapesticide.org.cn/ywb/index. jhtml). The losses caused by Phytophthora diseases of some commercial crops have been reduced through the use of metalaxyl, dimethomorph, azoxystrobin, and fluazinam (Matheron and Porchas 2000; Simons et al. 1990). However, fungicide resistance has become a major challenge as time goes by (Lu et al. 2010). For instance, resistance to metalaxyl and mefenoxam, a phenylamide fungicide highly effective against $P$. capsici, has been frequently reported at levels that have significantly increased the difficulty of managing Phytophthora diseases (Keinath 2007). Furthermore, previous study demonstrated that $P$. capsici was not highly sensitive to azoxystrobin in America (Matheron and Porchas 2000) and China (Qian et al. 2006). This spread of resistance to these fungicides has resulted in the need to identify new, alternative fungicides with different modes of action to replace the fungicides commonly used to control Phytophthora blight of pepper.

To date, few biopesticides have been registered in China to control Phytophthora blight of pepper. Tetramycin, the fermentation metabolite of Streptomyces ahygroscopicus subsp. wuzhouensis 11371,

${ }^{\dagger}$ Corresponding author: F. Liu; E-mail: fliu@sdau.edu.cn

Funding: This study was supported by the National Key Research Development Program of China, grant number (2017YFD0201600).

*The $\boldsymbol{e}$-Xtra logo stands for "electronic extra" and indicates that two supplementary tables are published online.

Accepted for publication 20 November 2017.

C) 2018 The American Phytopathological Society exhibits excellent inhibitory activity against many plant pathogens, including Passalora fulva, Botrytis cinera, and Pyricularia oryzae Cavara (Chen et al. 2017; Song et al. 2016; Zhong et al. 2010). Tetramycin is active against yeasts and fungi but inactive against bacteria (Dornberger et al. 1971). Thus, tetramycin is currently registered to manage rice and fruit crop diseases in China (Zhao et al. 2010). Tetramycin is a 26-member tetraene macrolide antibiotic that contains two active components (A and B) (Ren et al. 2014). The chemical structure of tetramycin could be found on Pubchem (https://www.ncbi.nlm.nih. gov/). Formulated tetramycin is stable in neutral and acidic solutions and has an excellent biological effect on several groups of plant pathogens, including ascomycetes, basidiomycetes, and adelomycetes (Wang et al. 2014). Furthermore, tetramycin can also enhance the disease resistance of plants to prevent pathogen infection by increasing the activity of phenylalanine ammonialyase, peroxidase, and polyphenol oxidase (Zhong et al. 2010). As the public grows increasingly concerned about the environment, the interest in biopesticides has grown because of their safe, efficient, and environmentally friendly properties (Wang et al. 2014). To our knowledge, tetramycin has not been registered for the controlling of Phytophthora blight of pepper in China (http://www.chinapesticide.org.cn), and limited information is available regarding its activity. Therefore, it is important to establish the baseline sensitivity of $P$. capsici to tetramycin before registering this compound for the control of Phytophthora blight of pepper.

The objectives of this study were to (i) test the biological activity of tetramycin against $P$. capsici in vitro; (ii) establish the baseline sensitivity of mycelia, sporangia, and zoospore of isolates of $P$. capsici from southern China; (iii) determine whether there is cross-resistance between tetramycin and other fungicides that are commonly used to control pepper Phytophthora blight in China; (iv) evaluate the protective and curative activity of tetramycin to control $P$. capsici on detached pepper leaves; and (v) evaluate the control efficacy (CE) of tetramycin against pepper Phytophthora blight in greenhouse experiments. This study would provide alternatives for the management of root and crown rot caused by $P$. capsici.

\section{Materials and Methods}

Isolates of $\boldsymbol{P}$. capsici. According to the method described by Jang et al. (2009), 90 isolates of $P$. capsici, causing capsicum epidemic disease, were collected and separated during 2015 to 2017 from Yunnan $(n=24)$, Fujian $(n=22)$, Jiangxi $(n=16)$, Zhejiang $(n=$ $14)$, and Guangdong $(n=14)$ provinces (Table 1). The sampling 
fields had not been exposed to tetramycin or other antibiotics. Mycelial plugs were transferred to $2-\mathrm{ml}$ sterile tubes containing sterile distilled water and kept at $18^{\circ} \mathrm{C}$ for long-term storage (Hu et al. 2013).

Fungicides. A technical concentrate of tetramycin (15\% active ingredient [a.i.]; Liaoning Wkioc Bioengineering Co., Ltd.) was used in the assays for biological activity and baseline sensitivity. Technicalgrade mandipropamid (93\% a.i.; Syngenta Crop Protection Company), azoxystrobin (95\% a.i.), mefenoxam (91\% a.i.), and fluazinam (98\% a.i.) (all supplied by Shandong Weifang Rainbow Chemical Co., Ltd.) fluopicolide (97\% a.i.; Dezhou Luba Fine Chemical Co., Ltd), and famoxadone (98.5\% a.i.; Shaanxi Meibang Pesticide Co., Ltd.) were used to determine the correlation between tetramycin and other commonly oomycete fungicides. Mandipropamid and fluopicolide were dissolved in acetone to prepare the stock solutions of $1 \times 10^{4} \mu \mathrm{g} \mathrm{ml}^{-1}$, while the other fungicides were suspended in methanol and stored at $4{ }^{\circ} \mathrm{C}$ in the dark to preserve the activity of the compounds. Formulated tetramycin $(0.3 \%$ AS; Liaoning Wkioc Bioengineering Co., Ltd.), cyazofamid (Segway, $100 \mathrm{~g} \mathrm{liter}^{-1}$ suspension concentrate [SC]; Ishihara Sangyo Kaisha Ltd.), and mefenoxam (Apron XL solution for seed treatment [LS], $350 \mathrm{~g} \mathrm{liter}^{-1}$ emulsion for seed treatment [ES]; Syngenta Crop Protection Company) were used in the studies of their ability to prevent and cure Phytophthora blight in lab studies and greenhouse experiments.

Effects on mycelial growth, sporangia formation, and zoospore discharge. Three $P$. capsici isolates (KM-3, HZ-7, and FZ-9), isolated and purified from the main pepper-producing areas (Yunnan, Zhejiang, and Fujian), were used to test the effect of tetramycin on mycelial growth, sporangia formation, and zoospore discharge.

The effect of tetramycin on the mycelial growth of $P$. capsici was assessed following the method of Sun et al. (2010), with minor modifications. The isolates were incubated on $\mathrm{V} 8$ media at $25^{\circ} \mathrm{C}$ for 4 days in the dark. Mycelial plugs $(5 \mathrm{~mm})$ were cut from these cultures and then placed on V8 juice agar medium (200 $\mathrm{ml}$ of V8 juice, $1 \mathrm{~g}$ of $\mathrm{CaCO}_{3}, 17 \mathrm{~g}$ of agar, and $800 \mathrm{ml}$ of distilled water) amended with tetramycin to give a final concentration of $0,0.1,0.5,1.0,2.5$, and $5.0 \mu \mathrm{g} \mathrm{ml}^{-1}$. The final solvent concentrations were all adjusted to be less than $1 \%$ in media. The radial mycelial growth was measured after 4 days of incubation at $25^{\circ} \mathrm{C}$ in the dark. Each treatment had four replicates.

The sporangia were produced by growing $P$. capsici on V8 media, as described by Matheron and Porchas (2000). Four agar plugs that were $5 \mathrm{~mm}$ in diameter were removed from the margin of an actively growing V8 culture and placed in a series of plastic petri dishes that were $90 \mathrm{~mm}$ in diameter containing $15 \mathrm{ml}$ of sterile distilled water amended with tetramycin at a series of concentrations of $0,0.05,0.1$, $0.5,0.75$, and $1.0 \mu \mathrm{g} \mathrm{ml}^{-1}$. After incubation for $48 \mathrm{~h}$ at $25^{\circ} \mathrm{C}$ with a 12-h photoperiod, the sporangia of each agar disc were counted under a light microscope with three fields of view for each mycelial disc. Three replicate plates were used for each treatment.

According to the description of Miao et al. (2015), 10 mycelial plugs were cut from V8 cultures that had been stimulated to produce sporangia and placed in petri discs containing $15 \mathrm{ml}$ of sterile distilled water amended with tetramycin at concentrations of $0,0.1$, $0.5,1.0,2.5$, and $5.0 \mu \mathrm{g} \mathrm{ml}^{-1}$. The petri dishes were maintained at $4^{\circ} \mathrm{C}$ for $30 \mathrm{~min}$ before raising the temperature back to $25^{\circ} \mathrm{C}$ for $30 \mathrm{~min}$. Each disc was observed microscopically at $\times 10$ by 10 with three fields of view for each mycelial disc to determine the numbers of the empty sporangia. Each treatment consisted of three replicate plates.

Baseline sensitivity of $\boldsymbol{P}$. capsici to tetramycin. In total, 90 isolates of P. capsici collected from southern China during 2015 to 2017 were used to determine the baseline sensitivity to tetramycin. The sensitivity assays were based on the measurements of mycelial growth and the inhibition of sporangia formation and zoospore discharge as described above. The fungicide concentration that reduced the mycelial growth, sporangia formation, and zoospore discharge by $50 \%$ compared with the control $\left(\mathrm{EC}_{50}\right.$ value) was calculated for each isolate. The $\mathrm{EC}_{50}$ values were calculated by performing a regression of the percent relative growth against the $\log _{10}$ fungicide concentrations with PROC GLM of SAS.

Correlation of $P$. capsici sensitivity to tetramycin and other widely used fungicides. In total, $45 P$. capsici isolates were randomly selected from the isolate collection to determine the crossresistance relationship between tetramycin and other most commonly used fungicides in $P$. capsici. The sensitivity of the $P$. capsici isolates to six fungicides belonging to several chemical classes (mandipropamid: $0.01,0.05,0.1,0.5$, and $1.0 \mu \mathrm{g} \mathrm{ml}^{-1}$; azoxystrobin: $0.5,1.0,2.5$, 5.0, and $10 \mu \mathrm{g} \mathrm{ml}^{-1}$; mefenoxam: 1.0, 5.0, 10, 25, and $50 \mu \mathrm{g} \mathrm{ml}^{-1}$; fluazinam: $0.5,1.0,2.5,5.0$, and $10 \mu \mathrm{g} \mathrm{ml}^{-1}$; fluopicolide: $0.1,0.5$, 2.5, 5.0, and $10 \mu \mathrm{g} \mathrm{ml}^{-1}$; and famoxadone: 1.0, 5.0, 25, 50, and $100 \mu \mathrm{g} \mathrm{ml}^{-1}$ ) was tested based on its mycelial growth (Lu et al. 2010). All of the fungicide treatments were analyzed on V8 media. To prevent the pathogens from utilizing an alternative mechanism of respiration, salicylhydroxamic acid (SHAM) at $100 \mu \mathrm{g} \mathrm{ml}^{-1}$ was added to the medium amended with azoxystrobin in the mycelial growth assays (Rebollar-Alviter et al. 2007).

Protective and curative activity of tetramycin on leaves of pepper. The ex vivo protective and curative activities of tetramycin were determined primarily as described previously by $\mathrm{Li}$ et al. (2007). The sixth expanded leaves were obtained from an experimental pepper greenhouse that had never been sprayed with fungicide. The leaves were rinsed with sterilized water and subsequently air dried, taking care to use leaves that were uniform in size and shape.

Leaves were inoculated with a $P$. capsici isolate (FZ-2) that exhibited decreased sensitivity to fungicides tested in this study, except for tetramycin. Each treatment was applied by spraying pepper leaves with a hand-held sprayer. Leaves were inoculated by a sterile fine needle and then sprayed with tetramycin at 30,60 , and $90 \mu \mathrm{g} \mathrm{ml}^{-1}$, with the reference fungicides mefenoxam and cyazofamid applied at doses of 250 and $100 \mu \mathrm{g} \mathrm{ml}^{-1}$, respectively. The control leaves were sprayed with deionized water. Treatments were applied $24 \mathrm{~h}$ prior to inoculation for the protective treatments or after inoculation for the curative treatments. All of the leaves were maintained in a moist chamber at $25^{\circ} \mathrm{C}$ for 4 days to allow the disease to develop. Each treatment consisted of 10 replicate plates, and the experiment was repeated three times. Disease severity was then determined by counting the lesion area accounts for the percentage of the whole leaf. The protective and curative $\mathrm{CE}$ were calculated as follows: $\mathrm{CE}(\%)=$ [(the average percentage of lesion area of water control - the average

Table 1. Baseline sensitivity of Phytophthora capsici isolates obtained from five provinces to tetramycin ${ }^{\mathrm{z}}$

\begin{tabular}{|c|c|c|c|c|c|c|c|c|c|c|}
\hline \multirow[b]{3}{*}{ Location } & \multirow[b]{3}{*}{$N$} & \multicolumn{9}{|c|}{$E_{50}$ for inhibition of } \\
\hline & & \multicolumn{3}{|c|}{ Mycelial growth $\left(\mu \mathrm{g} \mathrm{ml}^{-1}\right)$} & \multicolumn{3}{|c|}{ Sporangia production $\left(\mu \mathrm{g} \mathrm{ml}^{-1}\right)$} & \multicolumn{3}{|c|}{ Zoospore discharge $\left(\mu \mathrm{g} \mathrm{ml}^{-1}\right)$} \\
\hline & & Range & Mean & SD & Range & Mean & SD & Range & Mean & SD \\
\hline Kunming, Yunnan & 24 & $0.36-3.29$ & $1.77 \mathrm{a}$ & 0.77 & $0.15-4.57$ & $0.89 \mathrm{a}$ & 1.06 & $0.27-2.19$ & $0.73 \mathrm{a}$ & 0.50 \\
\hline Fuzhou, Fujian & 22 & $0.17-3.02$ & $0.71 \mathrm{a}$ & 0.93 & $0.12-1.07$ & $0.38 \mathrm{a}$ & 0.33 & $0.43-1.34$ & $0.77 \mathrm{a}$ & 0.34 \\
\hline Nanchang, Jiangxi & 16 & $0.31-2.27$ & $0.95 \mathrm{a}$ & 0.83 & $0.12-0.48$ & $0.31 \mathrm{a}$ & 0.15 & $0.07-0.54$ & $0.35 \mathrm{a}$ & 0.20 \\
\hline Hangzhou, Zhejiang & 14 & $0.16-3.09$ & $1.27 \mathrm{a}$ & 1.16 & $0.22-0.39$ & $0.31 \mathrm{a}$ & 0.09 & $0.31-0.63$ & $0.43 \mathrm{a}$ & 0.14 \\
\hline Guangzhou, Guangdong & 14 & $0.27-2.76$ & $1.08 \mathrm{a}$ & 0.97 & $0.38-0.63$ & $0.50 \mathrm{a}$ & 0.12 & $0.34-0.70$ & $0.50 \mathrm{a}$ & 0.15 \\
\hline
\end{tabular}

${ }^{\mathrm{z}} \mathrm{EC}_{50}=$ the fungicide concentration that reduced mycelial growth, sporangia formation, and zoospore discharge by $50 \%$ compared with the control. $N=$ number of isolates. Mean values followed by the same letter in the columns were not significantly different in Fisher's least significant difference test at $P=0.05$. SD $=$ standard deviation. 
percentage of lesion area of treatments)/(the average percentage of lesion area of water control)] $\times 100$.

Greenhouse experiments. To evaluate the protective and curative activities of tetramycin, greenhouse experiments were conducted with 45-day-old pepper seedlings of the cultivar Pepper Champion. The six treatments were as follows: (i) tetramycin $(0.3 \% \mathrm{AS})$ applied at 30,60 , and $90 \mu \mathrm{g} \mathrm{ml}^{-1}$; (ii) mefenoxam (350 $\left.\mathrm{g} \mathrm{liter}^{-1} \mathrm{EC}\right)$ applied at $250 \mu \mathrm{g} \mathrm{ml}^{-1}$; (iii) cyazofamid (100 $\mathrm{g} \mathrm{liter}^{-1} \mathrm{SC}$ ) applied at $100 \mu \mathrm{g} \mathrm{ml}^{-1}$; and (iv) a water treatment control.

A zoospore suspension of the isolate was prepared in advance as described by Kim et al. (1989) at a concentration of $1 \times 10^{4}$ zoospores $\mathrm{ml}^{-1}$. Each pepper was artificially infected with $5 \mathrm{ml}$ of a zoospore suspension of $P$. capsici. Fungicides were sprayed at $24 \mathrm{~h}$ after inoculation for the curative treatments or prior to inoculation for the protective treatments. After incubation, the pepper seedlings were maintained at $26^{\circ} \mathrm{C}$ in a moist chamber for 7 days. The disease development status of the inoculated plants was examined daily, and the incidence rate was counted. Each treatment consisted of 10 pots, and the greenhouse experiment was repeated twice. Each plant was scored according to how much the entire plant was diseased. The disease incidence and CE were calculated using the following equations: disease incidence $=[($ number of diseased plant $) /($ total plant investigated) $] \times 100 \%$ and CE $(\%)=[$ (the average percentage of lesion area of water control- the average percentage of lesion area of treatments)/(the average percentage of lesion area water control)] $\times 100 \%$.

Data analysis. All of the data were analyzed with the SAS statistical software package (version 9.4; SAS Institute Inc.). The $\mathrm{EC}_{50}$ value for each isolate was calculated by regression analysis using the percentage of growth inhibition plotted against the $\log _{10}$ fungicide concentration. The sensitivity to tetramycin was plotted against the sensitivity to mandipropamid, azoxystrobin, mefenoxam, fluazinam, fluopicolide, and famoxadone. The $\mathrm{EC}_{50}$ values were transformed to $\log _{10}$ values before determining the analysis of cross-resistance, and Pearson correlation coefficients $(r)$ were calculated in SAS. The CE data in detached-leaf assays and the greenhouse experiments were arcsine transformed prior to analysis. The procedure GLM was used for variance analysis, and Fisher's least-significant difference test at $P=0.05$ was used to separate the means.

\section{Results}

Effects on mycelial growth, sporangia formation, and zoospore discharge. The three $P$. capsici isolates (KM-3, HZ-7, and FZ-9) selected from isolate collections had similar biological activities at all tetramycin concentrations. Therefore, the data were combined. The mean mycelial growth, sporangia formation, and zoospore discharge values caused by tetramycin were employed to probit analysis (Fig. 1 ), and the $\mathrm{EC}_{50}$ values ranged from 1.17 to $1.19,0.63$ to 0.64 , and 0.62 to $0.63 \mu \mathrm{g} \mathrm{ml} \mathrm{g}^{-1}$, respectively. Tetramycin strongly inhibited the mycelial growth, sporangia formation, and zoospore discharge. In addition, the sporangia formation and zoospore discharge were more sensitive to tetramycin. Tetramycin at $5 \mu \mathrm{g} \mathrm{ml}^{-1}$ completely inhibited the formation of sporangia and the discharge of zoospores. The inhibition rates of the mycelial growth were greater than $90 \%$ at a concentration of $20 \mu \mathrm{g} \mathrm{ml}^{-1}$.

Baseline sensitivity to tetramycin on the inhibition of mycelial growth. We examined 90 single-spored isolates for their sensitivities to tetramycin based on their degree of mycelial growth. The sensitivities of the isolates collected from Yunnan, Fujian, Jiangxi, Zhejiang, and Guangdong were compared (Table 1). There was no significant difference $(P=0.11)$ in the sensitivities of isolates from different regions to tetramycin, and the mean $\mathrm{EC}_{50}$ values were 1.77, 0.71, 0.95, 1.27 , and $1.08 \mu \mathrm{g} \mathrm{ml}^{-1}$, respectively. The frequency distribution of the $\mathrm{EC}_{50}$ values fit a unimodal curve (Fig. 2A). Values ranged from 0.16 to $3.29 \mu \mathrm{g} \mathrm{ml}^{-1}$, with a mean value of $1.18 \pm 0.91 \mu \mathrm{g} \mathrm{ml}^{-1}$. The variation factor (highest $\mathrm{EC}_{50}$ value divided by lowest $\mathrm{EC}_{50}$ value) was 20.5.

Baseline sensitivity to tetramycin in a sporangia formation assay. There was also no detectable variation $(P=0.38)$ in the sensitivities of the sporangia formation to tetramycin from the five different sources of isolates. Mean $\mathrm{EC}_{50}$ values of $0.89,0.38,0.31$,
0.31 , and $0.50 \mu \mathrm{g} \mathrm{ml}^{-1}$ were found in the Yunnan, Fujian, Jiangxi, Zhejiang, and Guangdong populations, respectively (Table 1). The frequency distribution of the $\mathrm{EC}_{50}$ values of the inhibition of the formation of sporangia also fit a unimodal curve (Fig. 2B). The $\mathrm{EC}_{50}$ values ranged from 0.12 to $4.57 \mu \mathrm{g} \mathrm{ml}^{-1}$, with a mean of $0.64 \pm$ $0.42 \mu \mathrm{g} \mathrm{ml}^{-1}$ and a variation factor of 38.1.

Baseline sensitivity to tetramycin based on zoospore discharge. Zoospore discharge of the $90 \mathrm{P}$. capsici isolates was also assessed to

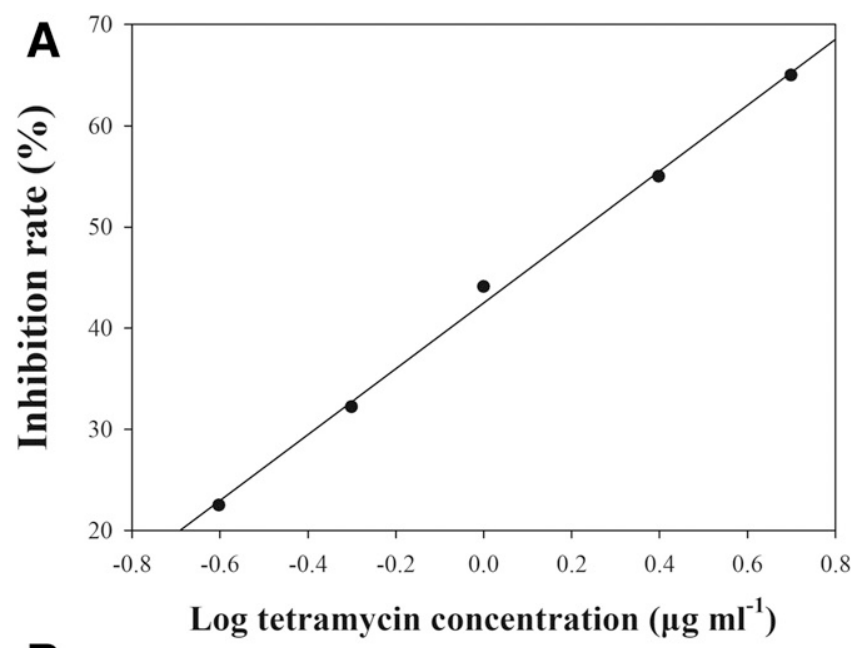

B
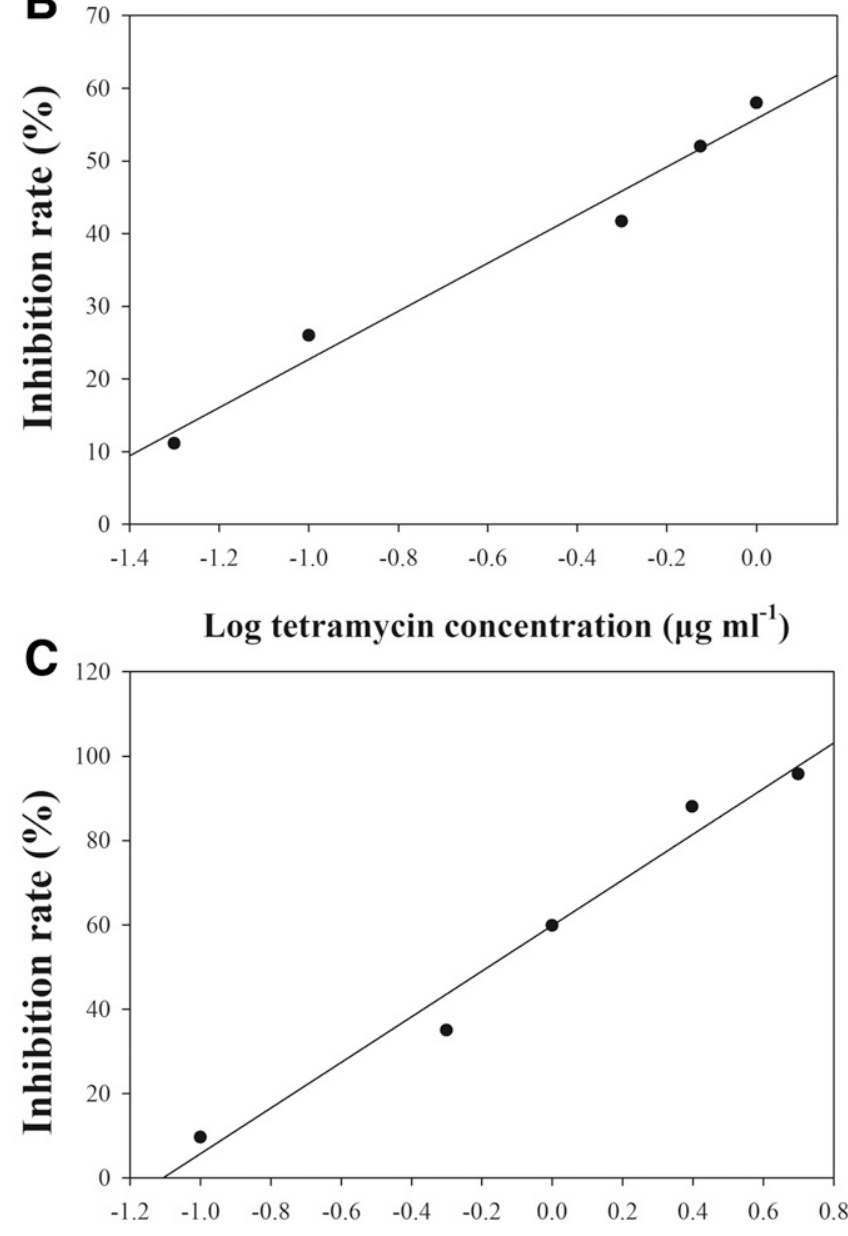

Log tetramycin concentration $\left(\mu \mathrm{g} \mathrm{ml}^{-1}\right)$

Fig. 1. Inhibition rate (\%) of $\mathbf{A}$, mycelial growth; $\mathbf{B}$, sporangia formation; and $\mathbf{C}$, zoospore discharge for three Phytophthora capsici isolates treated with tetramycin at different concentrations. The data represent the mean of three $P$. capsici isolates (KM-3, HZ-7, and FZ-9). The sensitivity of $P$. capsici to tetramycin was determined on V8 media. 
determine their sensitivities to tetramycin. There was no evident variation $(P=0.27)$ in the sensitivities of these isolates to tetramycin as well, and mean $\mathrm{EC}_{50}$ values of $0.73,0.77,0.35,0.43$, and $0.50 \mu \mathrm{g} \mathrm{ml}^{-1}$ were observed for the Yunnan, Fujian, Jiangxi, Zhejiang, and Guangdong populations, respectively (Table 1). The frequency distribution of the $\mathrm{EC}_{50}$ values for the 90 isolates was a unimodal curve (Fig. 2C), ranging from 0.07 to $2.19 \mu \mathrm{g} \mathrm{ml}^{-1}$, with a mean value of $0.63 \pm 0.30 \mu \mathrm{g} \mathrm{ml}^{-1}$ and a variation factor of 31.3 .
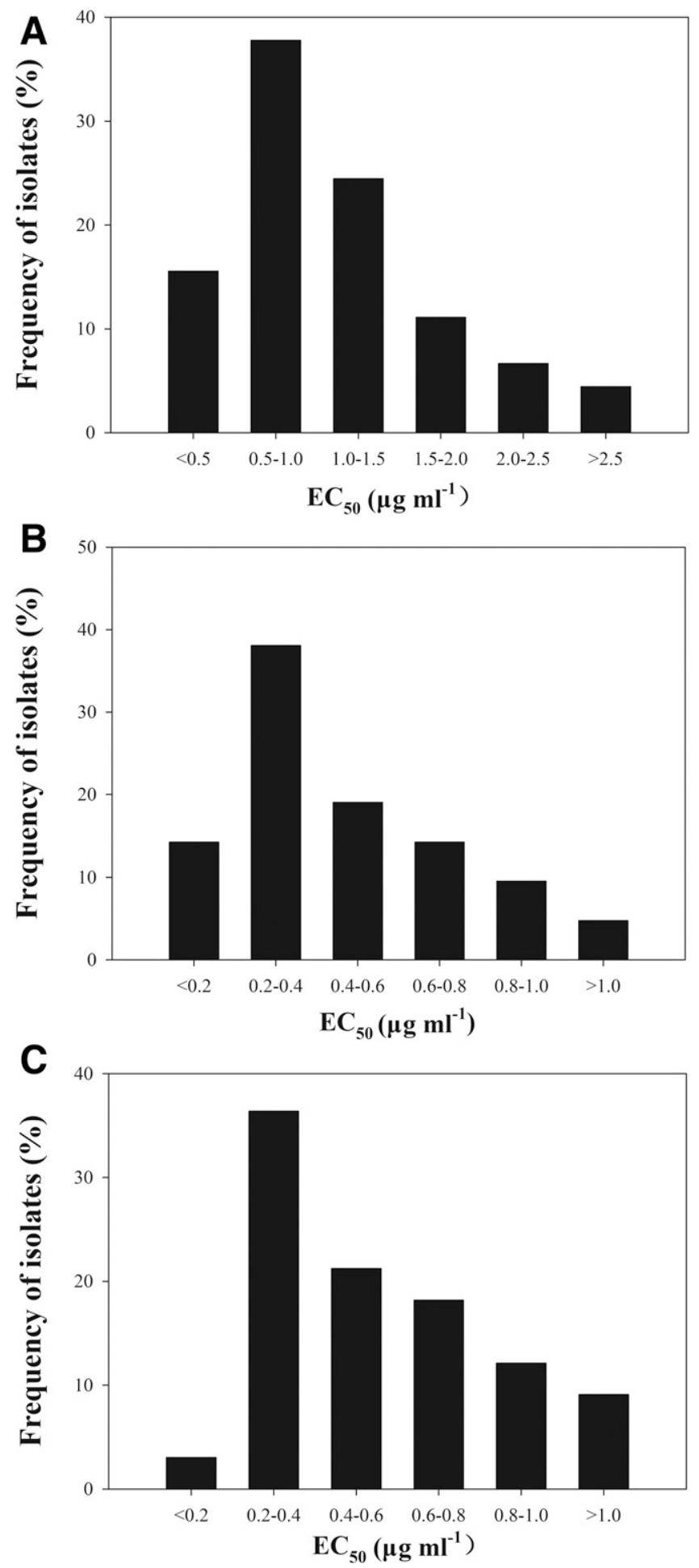

Fig. 2. Frequency distribution of the fungicide concentration that reduced mycelial growth, sporangia formation, and zoospore discharge by $50 \%$ compared with the control $\left(E_{50}\right)$ of 90 Phytophthora capsici isolates to tetramycin $\mathbf{A}$, mycelial growth; B, sporangia formation; and C, zoospore discharge for $P$. capsici isolates with tetramycin at several concentrations.
Correlation of $\boldsymbol{P}$. capsici sensitivity to tetramycin and other oomycete fungicides. The $45 \mathrm{P}$. capsici isolates, selected to determine the cross-resistance relationship of $P$. capsici sensitivity to tetramycin and most commonly used fungicides, exhibited various levels of sensitivity to mandipropamid, azoxystrobin, mefenoxam, fluazinam, fluopicolide, and famoxadone (Table 2). Tetramycin sensitivity was plotted against the sensitivity to mandipropamid, azoxystrobin, mefenoxam, fluazinam, fluopicolide, and famoxadone. Pearson correlations and regression analyses were utilized to test the log-transformed $\mathrm{EC}_{50}$ values. For the tetramycin combinations tested, the correlation coefficients ranged from -0.35 to $0.16(P>0.05)$ (Supplementary Table $\mathrm{S} 1$ ). Therefore, no significant correlation was observed between tetramycin sensitivity and the sensitivity to other fungicides tested in this study.

Protective and curative activity of tetramycin on the leaves of pepper. The protective and curative activity of tetramycin against $P$. capsici on detached pepper leaves was determined. In this study, tetramycin exhibited both protective and curative effects on the pepper leaves. The protective and curative activities of tetramycin increased as the concentration increased. The application of tetramycin at $90 \mu \mathrm{g} \mathrm{ml}^{-1}$ resulted in a CE of $63.8 \%$ when the protective activity was measured. Tetramycin applied at $90 \mu \mathrm{g} \mathrm{ml}^{-1}$ provided a good CE that differed significantly $(P<0.05)$ compared with the reference fungicides mefenoxam and cyazofamid. The $\mathrm{CE}$ of tetramycin at $90 \mu \mathrm{g} \mathrm{ml}^{-1}$ reached $48.5 \%$, which was considerably higher than the $\mathrm{CE}$ of cyazofamid applied at $100 \mu \mathrm{g} \mathrm{ml}^{-1}$ when the curative activity was measured (Table 3; Fig. 3).

Greenhouse experiments. The protective efficacy of tetramycin increased significantly $(P<0.05)$ with the increase in concentration.

Table 2. Sensitivity of Phytophthora capsici isolates obtained from southern China to seven fungicides

\begin{tabular}{|c|c|c|c|c|}
\hline \multirow[b]{2}{*}{ Fungicide } & \multirow[b]{2}{*}{$N^{\mathbf{z}}$} & \multicolumn{3}{|c|}{$\begin{array}{l}\mathbf{E C}_{50} \text { for inhibition of mycelial growth } \\
\qquad\left(\mu \mathrm{g} \mathrm{ml}^{-1}\right)^{\mathrm{y}}\end{array}$} \\
\hline & & Range & Mean & SD \\
\hline Tetramycin & 45 & $0.01-3.82$ & $0.15 \mathrm{~b}$ & 1.01 \\
\hline Mandipropamid & 45 & $0.01-0.05$ & $0.02 \mathrm{~b}$ & 0.01 \\
\hline Azoxystrobin & 45 & $0.10-0.48$ & $0.20 \mathrm{~b}$ & 0.08 \\
\hline Mefenoxam & 45 & $0.37-16.8$ & $6.24 \mathrm{~b}$ & 3.94 \\
\hline Fluazinam & 45 & $0.30-118$ & $16.7 \mathrm{~b}$ & 23.5 \\
\hline Fluopicolide & 45 & $0.22-198$ & $12.1 \mathrm{~b}$ & 31.5 \\
\hline Famoxadone & 45 & $10.5-996$ & $407 \mathrm{a}$ & 294 \\
\hline
\end{tabular}

${ }^{\mathrm{y}} \mathrm{EC}_{50}$ values are the effective concentrations of fungicide that inhibited mycelial growth on V8 medium by $50 \%$. Mean values followed by the same letter in the columns were not found to be significantly different by Fisher's least significant difference test at $P=0.05$. SD $=$ standard deviation.

${ }^{\mathrm{z}}$ Isolates were collected from Yunnan, Fujian, Jiangxi, Zhejiang, and Guangdong provinces in China during 2015 to 2017. In total, 45 P. capsici isolates were randomly selected to determine the cross-resistance relationship of $P$. capsici sensitivity to tetramycin and most commonly used fungicides.

Table 3. Protective and curative activity of tetramycin against pepper Phytophthora blight on leaves of pepperv

\begin{tabular}{|c|c|c|c|c|c|}
\hline \multirow[b]{2}{*}{ Fungicidew $^{w}$} & \multirow[b]{2}{*}{$\mathrm{EC}\left(\mu \mathrm{g} \mathrm{ml}^{-1}\right)^{\mathrm{x}}$} & \multicolumn{2}{|c|}{ Protective activity } & \multicolumn{2}{|c|}{ Curative activity } \\
\hline & & $\operatorname{LAP}(\%)^{\mathrm{y}}$ & $\mathrm{CE}(\%)^{\mathrm{z}}$ & LAP (\%) & CE $(\%$ \\
\hline \multirow[t]{3}{*}{ Tetramycin } & 30 & $76.9 \mathrm{a}$ & $15.1 \mathrm{~d}$ & $64.6 \mathrm{~b}$ & $27.9 \mathrm{~b}$ \\
\hline & 60 & $59.4 \mathrm{~b}$ & $34.4 \mathrm{c}$ & $51.9 \mathrm{c}$ & $42.1 \mathrm{a}$ \\
\hline & 90 & $32.8 \mathrm{c}$ & $63.8 \mathrm{~b}$ & $46.2 \mathrm{~cd}$ & $48.5 \mathrm{a}$ \\
\hline Mefenoxa & 250 & $20.0 \mathrm{~d}$ & $77.9 \mathrm{a}$ & $43.8 \mathrm{~d}$ & $51.1 \mathrm{a}$ \\
\hline Cyazofamid & 100 & $58.4 \mathrm{~b}$ & $35.5 \mathrm{c}$ & $86.0 \mathrm{a}$ & 3.99 \\
\hline
\end{tabular}

$\mathrm{v}$ Experiments were performed in the lab in 2017. Mean values followed by the same letter in the columns were not significantly different according to Fisher's least significant difference test at $P=0.05$.

${ }^{\mathrm{w}}$ Each treatment was sprayed until runoff with a hand-held sprayer and air dried for $1 \mathrm{~h}$.

${ }^{\mathrm{x}} \mathrm{EC}=$ effective concentrations of fungicide that inhibited mycelial growth.

${ }^{y} \mathrm{LAP}=$ lesion area percentage.

${ }^{\mathrm{z}} \mathrm{CE}=$ control efficacy. 
At the highest test concentration of tetramycin $\left(90 \mu \mathrm{g} \mathrm{ml}^{-1}\right)$, the CE ranged from 29.0 to $56.4 \%$ in the assays for protective activity. When applied at $90 \mu \mathrm{g} \mathrm{ml}^{-1}$, there were no significant differences $(P<0.05)$ in the efficacy of tetramycin and its reference fungicides mefenoxam and cyazofamid (Table 4).

Tetramycin applications of $90 \mu \mathrm{g} \mathrm{ml}^{-1}$ had a CE of $52.7 \%$ when the efficacy of curative was measured. In addition, tetramycin applied at $90 \mu \mathrm{g} \mathrm{ml}^{-1}$ provided a CE similar to that of the samples treated with mefenoxam and cyazofamid (Table 4).

\section{Discussion}

As we have seen, the effect of tetramycin on the different developmental stages of $P$. capsici has not been reported to date. This study revealed that tetramycin strongly inhibits the mycelial growth, sporangia formation, and zoospore discharge of P. capsici. Among the components of the life cycle of the $P$. capsici tested, tetramycin was the most effective at inhibiting the formation of the sporangia and the discharge of the zoospores (Fig. 1; Table 1). The different responses showed that the sensitivity of $P$. capsici to tetramycin differed among several life stages tested in our study. Because $P$. capsici produces three types of spores, any chemical that significantly suppresses multiple spore types, particularly sporangia formation and zoospore discharge, is considered to be useful to control Phytophthora blight of pepper (Matheron and Porchas 2000). Once infection has occurred, the suppression of the mycelial growth within the host tissue plays an important role in disease management (Matheron and Porchas 2000). Chen et al. (2017) reported that tetramycin can prevent disease from occurring by inhibiting the growth of the mycelia and the germination of spores. Subsequently, this fungicide can severely restrict the potential of $P$. capsici to infect plant issue.

It is of great concern to establish the baseline sensitivity of a new fungicide prior to introducing it into the market (Russell 2004); therefore, we can detect any shifts toward resistance in the populations by comparisons to the baseline sensitivity in isolates not exposed to tetramycin. In the current study, the baseline sensitivity curves for tetramycin were both unimodal in pathogen populations that had never

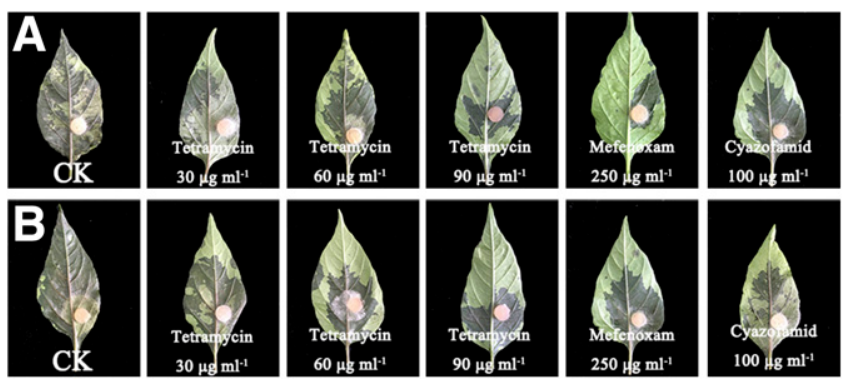

Fig. 3. A, Protective and B, curative activities of three tested fungicides (tetramycin, mefenoxam, and cyazofamid) against Phytophthora capsici on detached pepper leaves. Leaves inoculated with the $P$. capsici isolate (FZ-2) were maintained in a moist chamber at $25^{\circ} \mathrm{C}$ for 4 days. been exposed to tetramycin or other antibiotics (Fig. 2). This result indicated that there were no tetramycin-resistant subpopulations among the isolates tested in this study. Measurements of the inhibition of mycelial growth, sporangia formation, and zoospore discharge showed that the variation factors were both less than 40 , indicating a low variation in sensitivity among the isolates ( $\mathrm{Lu}$ et al. 2010). However, the narrow sensitivity range does not indicate that $P$. capsici has a reduced potential to develop resistance (Mamiev et al. 2013).

The lack of cross-resistance between tetramycin and other widely used fungicides such as mandipropamid, azoxystrobin, mefenoxam, fluazinam, fluopicolide, and famoxadone suggests that this phenomenon can be utilized in the management of fungicide resistance. However, this relationship needs to be studied further. Considering the small sample size, more than 45 isolates of $P$. capsici should be included in future monitoring efforts. Previous research has demonstrated that it was difficult to induce resistance to tetramycin in $B$. cinerea utilizing mutagenesis and ultraviolet light (Song et al. 2016). Additionally, there was no evident variation $(P>0.05)$ between the initial parental generation and its 20th generation (under selective pressure) for the germination rate and mycelial growth of $B$. cinerea (Ajouz et al. 2010). One possible reason for this is that tetramycin, as a mixture, failed to induce a single site mutation. In addition, the insensitivity of tetramycin has not been reported in other pathogens to date (Song et al. 2016). However, even though the atypical mode of action of polyene antibiosis makes the development of resistance unlikely, preventive measures should be adopted to avoid or delay the development of tetramycin resistance ( $\mathrm{Li}$ et al. 2014).

Tetramycin could reduce the lesion expansion of $P$. capsici on detached pepper leaves and effectively control Phytophthora blight of pepper in greenhouse experiments. The excellent protective and curative activity of tetramycin has been previously reported in rice blast, poplar canker, gray mold, and tomato leaf mold (Chen et al. 2017; Song et al. 2016; Wang et al. 2014; Zhao et al. 2010). Tetramycin had both protective and curative effects on the leaves of pepper, and its protective activity was better than its curative activity (Tables 3 and 4). A key component in modern agriculture is that fungicides have both protective and curative activity, and this factor can help to prevent the occurrence and spread of disease throughout the crop (Miao et al. 2015). The present study demonstrated that the protective and curative activity of tetramycin on detached pepper leaves was similar but not identical to its efficacy in greenhouse experiments (Tables 3 and 4). We hypothesized that this may be caused by the differences in the way the fungus was applied and inoculated. However, this finding merits additional study. It has been reported that the control efficiency of tetramycin applied at $3.75 \mu \mathrm{g} \mathrm{ml}^{-1}$ can reach $71 \%$ in field trials (Zhu et al. 2015). However, these experiments were conducted by a drip-irrigation technique. To further confirm its protective and curative activity, the $\mathrm{CE}$ of tetramycin against $P$. capsici in the field will be evaluated in our next study. In addition, tetramycin has not been used for controlling P. capsici in practice. It appears that tetramycin has the potential to be an excellent alternative fungicide to control Phytophthora blight of pepper.

Table 4. Protective and curative activity of tetramycin against pepper Phytophthora blight in a greenhouse experiment ${ }^{\mathrm{y}}$

\begin{tabular}{|c|c|c|c|c|c|c|c|}
\hline \multirow[b]{3}{*}{ Fungicide $^{\mathrm{z}}$} & \multirow[b]{3}{*}{ EC $\left(\mathrm{g} \mathrm{ha}^{-1}\right)$} & \multicolumn{6}{|c|}{7 days after treatments } \\
\hline & & \multicolumn{3}{|c|}{ Protective activity } & \multicolumn{3}{|c|}{ Curative activity } \\
\hline & & DR $(\%)$ & $\operatorname{LAP}(\%)$ & CE (\%) & DR (\%) & LAP (\%) & CE (\%) \\
\hline \multirow[t]{3}{*}{ Tetramycin } & 30 & 88.9 & $68.9 \mathrm{~b}$ & $29.0 \mathrm{c}$ & 100 & $69.7 \mathrm{~b}$ & $25.5 \mathrm{c}$ \\
\hline & 60 & 88.9 & $51.3 \mathrm{c}$ & $47.1 \mathrm{~b}$ & 100 & $53.0 \mathrm{c}$ & $43.3 \mathrm{~b}$ \\
\hline & 90 & 77.8 & $42.1 \mathrm{c}$ & $56.4 \mathrm{ab}$ & 100 & $44.2 \mathrm{~d}$ & $52.7 \mathrm{ab}$ \\
\hline Mefenoxam & 250 & 77.8 & $25.9 \mathrm{~d}$ & $73.2 \mathrm{a}$ & 77.8 & $45.0 \mathrm{~d}$ & $51.9 \mathrm{ab}$ \\
\hline Cyazofamid & 100 & 88.9 & $46.0 \mathrm{c}$ & $52.6 \mathrm{~b}$ & 88.9 & $39.9 \mathrm{~d}$ & $58.1 \mathrm{a}$ \\
\hline Control & $\ldots$ & 91.7 & $96.9 \mathrm{a}$ & $\ldots$ & 100 & $93.6 \mathrm{a}$ & $\ldots$ \\
\hline
\end{tabular}

y Experiments were employed with the cultivar Pepper champion in a greenhouse in 2017. Mean values followed by the same letter in the columns were not significantly different according to Fisher's least significant difference test at $P=0.05$. EC $=$ effective concentrations of fungicide that inhibited mycelial growth, $\mathrm{DR}=$ disease rate, $\mathrm{LAP}=$ lesion area percentage, and $\mathrm{CE}=$ control efficacy.

${ }^{\mathrm{z}}$ Each treatment was sprayed until runoff with a hand-held sprayer and air dried for $1 \mathrm{~h}$. 
As far as we know, this report is the first to describe the baseline sensitivity of $P$. capsici to tetramycin in China. The combination of our results suggests that tetramycin is an excellent candidate to use in $P$. capsici control programs. These reasons include the finding that no multiple resistance relationship between tetramycin and other fungicides tested was identified. Tetramycin had a high inhibitory activity on the different life stages of $P$. capsici. The compound exhibited strong protective and curative efficacy against Phytophthora blight of pepper in detached-leaf assays and greenhouse experiments. In addition, the application of conventional fungicides is increasingly being curtailed due to the safety and resistance development problems of these chemicals (Janisiewicz and Korsten 2002). In contrast, tetramycin is considered to simultaneously have low toxicity and be an environmentally friendly pesticide. However, to avoid the rapid development of tetramycin resistance in the future, appropriate antiresistance precautions are needed, including continuous sensitivity monitoring in $P$. capsici and the use of tetramycin and other oomycete-specific fungicides.

\section{Literature Cited}

Ajouz, S., Nicot, P. C., and Bardin, M. 2010. Adaptation to pyrrolnitrin in Botrytis cinerea and cost of resistance. Plant Pathol. 59:556-566

Bi, Y., Cui, X., Lu, X., Cai, M., Liu, X., and Hao, J. J. 2011. Baseline sensitivity of natural population and resistance of mutants in Phytophthora capsici to zoxamide. Phytopathology 101:1104-1111.

Chen, L. L., Guo, B. B., and Li, B. X. 2017. Toxicity and control efficacy of tetramycin against Passalora fulva. Chin. J. Pestic. Sci. 19:324-330.

Dornberger, K., Fügner, R., and Bradler, G. 1971. Tetramycin, a new polyene antibiotic. J. Antibiot. 24:172-177.

Granke, L. L., Windstam, S. T., and Hoch, H. C. 2009. Dispersal and movement mechanisms of Phytophthora capsici sporangia. Phytopathology 99:1258-1264.

Hausbeck, M. K., and Lamour, K. H. 2004. Phytophthora capsici on Vegetable Crops: Research Progress and Management Challenges. Plant Dis. 88:1292-1303.

Hu, J., Pang, Z., and Bi, Y. 2013. Genetically diverse long-lived clonal lineages of Phytophthora capsici from pepper in Gansu, China. Phytopathology 103:920-926.

Jang, H. S., Lee, S. M., and Sun, B. K. 2009. Baseline sensitivity to mandipropamid among isolates of Phytophthora capsici causing phytophthora blight on pepper. Plant Pathol. J. 25:317-321.

Janisiewicz, W. J., and Korsten, L. 2002. Biological control of postharvest diseases of fruits. Annu. Rev. Phytopathol. 40:411-441.

Keinath, A. P. 2007. Sensitivity of populations of Phytophthora capsici from south Carolina to mefenoxam, dimethomorph, zoxamide, and cymoxanil. Plant Dis. 91:743-748.

Kim, Y. J., Hwang, B. K., and Park, K. W. 1989. Expression of age related resistance in pepper plants infected with Phytophthora capsica. Plant Dis. 73: 745-747.

Lamour, K. H., Stam, R., and Jupe, J. 2011. The oomycete broad-host-range pathogen Phytophthora capsici. Mol. Plant Pathol. 13:329-337.

Li, H., Liu, J. B., and Wang, T. J. 2014. Research progress of ATP-binding cassette transporters in polyene antibiotic biosynthesis gene cluster. Microbiol. China. 415:950-958.
Li, Z. J., Long, W. P., and Zheng, J. R. 2007. In vitro leaf technique for the evaluation of pepper resistance to Phytophthora capsici. Hua Nan Nong Ye Da Xue Xue Bao 2:47-51.

Lu, X. H., Zhu, S. S., Bi, Y., Liu, X. L., and Hao, J. J. 2010. Baseline sensitivity and resistance-risk assessment of Phytophthora capsici to iprovalicarb. Phytopathology 100:1162-1168.

Mamiev, M., Korolev, N., and Elad, Y. 2013. Resistance to polyoxin AL and other fungicides in Botrytis cinerea, collected from sweet basil crops in Israel. Eur. J. Plant Pathol. 137:79-91.

Matheron, M. E., and Porchas, M. 2000. Impact of azoxystrobin, dimethomorph, fluazinam, fosetyl-Al, and metalaxyl on growth, sporulation, and zoospore cyst germination of three Phytophthora spp. Plant Dis. 84:454-458.

Miao, J., Dong, X., and Lin, D. 2015. Activity of the novel fungicide oxathiapiprolin against plant-pathogenic oomycetes. Pest Manage. Sci. 72: 1572-1577.

Qian, Z. H., Chen, C. J., and Wang, J. X. 2006. Baseline sensitivity of different morpha of Phytophthora capsici Leonian to azoxystrobin. Acta Phytopathol. Sin. 36:322-327.

Rebollar-Alviter, A., Madden, L. V., Jeffers, S. N., and Ellis, A. A. 2007. Baseline and differential sensitivity to two QoI fungicides among isolates of Phytophthora cactorum that cause leather rot and crown rot on strawberry. Plant Dis. 91:1625-1637.

Ren, J., Cui, Y., and Zhang, F. 2014. Enhancement of nystatin production by redirecting precursor fluxes after disruption of the tetramycin gene from Streptomyces ahygroscopicus. Microbiol. Res. 169:602-608.

Ristaino, J. B., Larkin, R. P., and Campbell, C. L. 1994. Spatial dynamics of disease symptom expression during phytophthora epidemics in bell pepper. Phytopathology 84:1015-1024.

Rubin, A. E., Gotlieb, D., and Gisi, U. 2008. Mutagenesis of Phytophthora infestans for resistance against carboxylic acid amide and phenylamide fungicides. Plant Dis. 92:675-683.

Russel, P. E. 2004. Sensitivity baselines in fungicide resistance research and management. FRAC Monograph No. 3. Online publication. FRAC, Brussels, Belgium. http://www.frac.info/docs/default-source/publications/monographs/ monograph-3.pdf?sfvrsn=8

Simons, J. N., Simons, J. E., and Simons, J. L. 1990. Control of phytophthora crown rot in bell pepper with directed sprays of metalaxyl. Proc. Fla. State Hortic. Soc. 103:120-121.

Song, Y., He, L., and Chen, L. 2016. Baseline sensitivity and control efficacy of antibiosis fungicide tetramycin against Botrytis cinerea. Eur. J. Plant Pathol 146:337-347.

Sun, H., Wang, H., and Stammler, G. 2010. Baseline sensitivity of populations of Phytophthora capsici, from China to three carboxylic acid amide (CAA) fungicides and sequence analysis of cholinephosphotranferases from a CAAsensitive isolate and CAA-resistant laboratory mutants. J. Phytopathol. 158: 244-252.

Wang, L. P., Chang, G. B., and Meng, S. 2014. Study on the poplar canker disease controlled using four hygromycin in field. J. Microbiol. 34:68-70.

Zhao, X. H., Zhong, L. J., and Zhang, Q. H. 2010. Effect of tetramycin on mycelial growth and spore germination of rice blast pathogen. J. Microbiol. 30:43-45.

Zhong, L. J., Zhao, X. H., and Zhang, Q. H. 2010. Rice resistance against blast induced by tetramycin. Plant Dis. Pests 38:6263-6344.

Zhu, S. X., Li, J., Wu, F., Xiang, J. H., and Yan, W. B. 2015. Screening fungicides for control of Phytophthora blight of pepper. Chin. Hortic. Abstr. 4:34-37. 